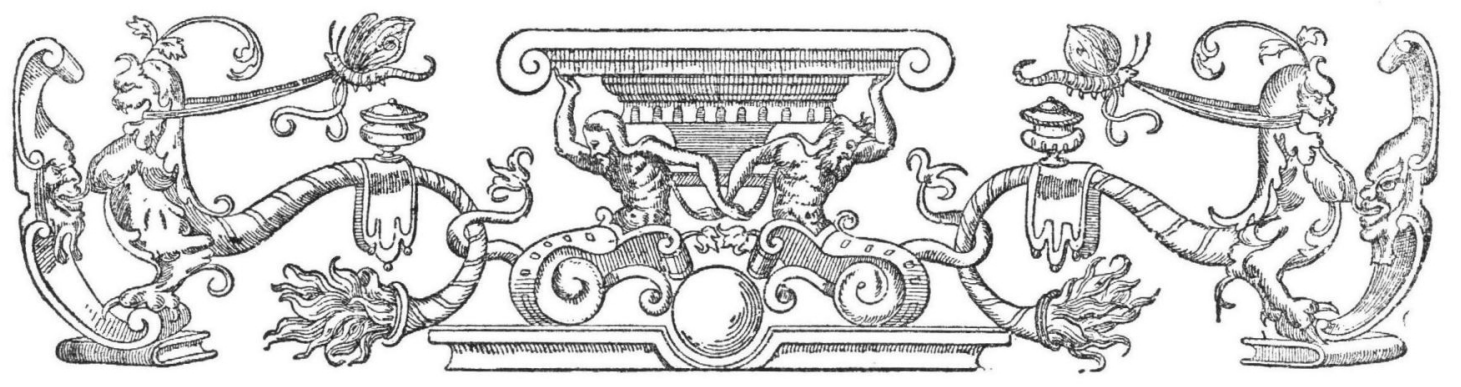

\title{
LEPROZEN EN LEPROZENHUIZEN
}

DOOR

H. D. J. VAN SCHEVICHAVEN.

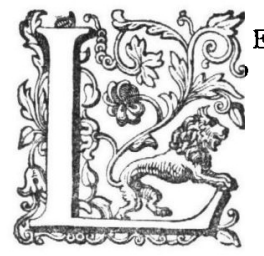

EPROZIJ, lazarij, melaatscheid zijn collectieve namen, gegeven aan verschillende ernstige chronische ziekten, welke gepaard gingen met een afschuwelijken huiduitslag en misvorming (elephantiasis), in zekere gevallen zelfs de ledematen deden afvallen. Veclal wordt beweerd dat deze ziekte door de kruistochten uit het Oosten naar Europa zou zijn overgeplant, doch dit is onjuist. De troepen van PoMPEjus hadden haar reeds uit Egypte naar Italië gebracht, zoodat $\lambda \varepsilon \pi \rho o_{s}$ aan de Grieken, "leprae" aan Plinius wel bekend waren; ook bepaalt een capitularium van KAREL DEN GROOTE uit het jaar 789: „Omtrent de leprozen, dat zij zich niet onder de andere menschen mogen mengen."

Wegens de besmettelijkheid dezer ziekte, begon men reeds vroeg hen die er door aangetast waren uit de samenleving te verwijderen. Even buiten de muren der middeleeuwsche steden placht men hospitalen of huizen te bouwen, waarin de leprozen werden opgenomen. Zulk een gesticht te doen verrijzen, werd een luxe van het vrome geloof, een sport in den ladder die ten hemel voerde. Er zouden dan ook in Frankrijk alleen, in de $\mathrm{I} 3^{\mathrm{e}}$ eeuw, niet minder dan 2000 zulke stichtingen geweest zijn. Gematigder echter is de schatting van den geschiedschrijver MatTheus Paris, die in de tweede helft der I 3 e eeuw leefde. Deze beweert, dat er destijds 1900 leprozenhuizen, ,in de gansche christenheid" waren. Oud-Holland 1907 . 
Zeker is het dat het aantal der ongelukkige lepralijders in de vroege middeleeuwen ontzaggelijk groot geweest moet zijn, zoodat het gezonde gedeelte der menschineid bijna radeloos werd onder de plaag. En toen daar vroeg in de I $4^{\mathrm{e}}$ eeuw nog een pest-epidemie bijkwam, meende men dat deze beide ziekten door kwaadwilligheid werden voortgeplant. Wie zich daaraan schuldig maakten was spoedig gevonden: dat waren natuurlijk de Joden, die steeds de bron van alle kwaad zijn geweest. De Moorsche koning van Grenada, heette het, had zich met hen verbonden om het Christendom uit te roeien. Te dien einde had Israël zich vereenigd met de leprozen, wien $z \mathrm{ij}$, met behulp des duivels, hadden opgestookt om zich te wreken over de uitstooting en verachting die hun allerwege te beurt vielen. Er waren lieden die beweerden een mengsel van menschenbloed en urine gevonden te hebben, met een gewijde hostie er in, en dat de melaten daarmede de bronnen vergiftigden. Op bevel van paus JoHANNES XXII, werden daarop in 1320 alom alle leprozen verbrand, die men in handen kon krijgen. De kroniekschrijver WILLEM, kapellaan te Brederode, later monnik in de abdij van Egmond, een tijdgenoot dier gebeurtenissen, die dit ongelooflijke verhaal heeft geboekt, voegt er bij dat deze gruwelijke maatregel "in alle landen" werd toegepast.

Er schijnen streken geweest te zijn, waar de melaatschheid epidemisch heerschte. Als zoodanig wordt Lombardije voorgesteld in de $8 \mathrm{e}$ eeuw. Toen KAREL DE GROOTE in 770 een oog van welgevallen had geworpen op DESIDERIA, dochter van Desiderius, koning van dat rijk, zond paus STEPHANUS III hem een schrijven om dat huwelijk af te raden. "Alle Lombardische vrouwen zijn ongezond", schreef zijn Heiligheid, "en het geheele volk is hoogst onwelriekend (foetentissima)". Overigens stond het vast, dat onder hen de melaatschheid ontstaan was (de cujus natione leprosorum genus oriri certum est). Keizer KAREL liet zich evenwel niet afschrilkken door deze waarschuwing: hij trouwde de prinses, maar - binnen het jaar zond hij haar aan haren vader terug. Reden onbekend.

Geen hooge rang, stand, noch geboorte, vrijwaarde voor deze vreeselijke ziekte. Zoo vertelt Slicutenhorst in zijn Geldersche Geschiedenissen, dat hertog ADOLF VAN GELRE zijn vader ARNOLD verweet, dat deze „een quaed verhoolen gebreck over hem hadde, 't welck men niet en moght naem-achtigh maeken, waermede hij en zijne landen byster waeren geplaeght geweesd; gelijck ook de Vorstin, die daerover niet zeer van hem was geliefkoosd en geeerd." Deze laatste zinspeling doelt op hertogin ELEANORE, ARNOLD's echtgenoote, en zuster van EnUARD III, koning van Engeland, die door haar man van leprozij beschuldigd en verstooten was, een geval dat door de dichters STARING en VAN LENNEP is bezongen.

Vroeg in de $2^{c}$ eeuw stonden er reeds buiten Parijs, aan den weg naar 
St. Denis, eenige barakken waarin de leprozen woonden. Koning LQDEwIJK VII bezocht hen daar in I I 47, vóór hij als kruisvaarder naar het $\mathrm{H}$. Land toog, „een lofwaardige daad, die veel navolging vond', merkt een van 's Konings tijdgenooten op, de kroniekschrijver JACQUES DE VITRY. Er vormden zich in die tijden van godsdienstige opwinding, vereenigingen van geestelijken en leeken, die de plicht op zich namen om de kranken in de leprozenhuizen te verplegen. „Om Christus' wille", zegt DE VITRY, ,verdroegen zij te midden van vuilheid en stanken zich zelven overwinnende, zulke ondragelijke ellende, dat geen boetedoening die men zich kan opleggen, in de oogen van Gods heiligen en kostelijke martelaren daarmede vergeleken worden kan." Het was dezelfde geloofsijver die een deel der ridders van St. Jan van Jeruzalem zich deed afscheidden van hun Orde, ten einde zich uitsluitend aan ziekenverpleging te wijden. Zij noemden zich de Orde van den 11. Lazarus en der H. Maagd van den berg Carmel. LodEwIJK IX bracht hen naar Frankrijk over, en droeg hun het toezicht op over de ziekenen leprozenhuizen, waarin zij door koninklijke besluiten van 1664 en $\mathbf{1} 672$ werden bevestigd. Onder hen werden deze huizen beheerd door monniken.

De inwoning in het melatenhuis was den leprozen hier te lande niet verplicht, de meesten verkozen daarboven de vrijheid en den bedelstaf. Luchtig en zorgeloos gingen $\mathrm{zij}$ het pad op, doch bij ernstige, vrome zielen ging het zich terugtrekken uit de menschelijke samenleving gepaard met een sombere indrukwekkende kerkelijke plechtigheid. Hoe deze in Nederland plaats greep is mij niet bekend, doch daar de kerkdiensten destijds in de geheele christenheid weinig verschilden, mag men aannemen dat het dezelfde was als bij onze oostelijke en westelijke naburen. De statuten der kapittelkerk van Toul, in Frankrijk, toonen ons in de volgende woorden hoe dit geschiedde in het geval van een domheer:

"Mocht het komen te gebeuren dat een melaatsche kanunnik, daartoe door den Heer opgewekt en aangedreven, zich uit demoedigheid in het openbaar liet uitstooten, dan moet de dienst zijner afsnijding (officium tallium) op de volgende plechtige wijze plaats grijpen. $\mathrm{Na}$ priem zal de gemeente samenkomen en de klok geluid worden. Dan moet het geheele kapittel, met het kruis voorop, hem aan zijn woning afhalen. De melaatsche kanunnik moet gekleed zijn in een zwart of in een wit gewaad, met zijn overkleed (superpellicium) en schoudermantel (almutia), evenals de overige kanunniken. Alleen begeve hij zich dan, achter het voor hem uitgedragen kruis, naar het koor. In het midden daarvan zij een koorstoel geplaatst, met een kleed bedekt; daarop zal hij plaats nemen. Dan moet een plechtige mis gezongen en zijn uitvaart gehouden worden. Wanneer de mis volbracht is, worde hij door het gansche kapittel, met het kruis voorop, naar het muurtje (murotum) buiten de kerk gebracht, waar een wagen gereed moet 
staan, om hem naar zijn woonplaats te voeren, steeds vooraf gegaan door het kruis, benevens een kanunnik-priester te paard, die hem in zijn woning opsluit. Zijn vrienden moeten hem volgen, den ganschen weg, ook al ware het een dagreize of zelfs verder."

De wijze waarop een godvreezend mclaatsch lidmaat der gemeente werd afgesneden van de menschelijke gemeenschap in het bisdom van Clermont en St. Flour, werd op de volgende, wel wat onduidelijke wijze, vastgesteld in I490: "Voor het altaar moet een zwart kleed uitgespreid zijn over twee schragen, die op eenigen aftand van elkander staan. Daar naast moet de melaat zich bevinden in knielende houding; en daar onder (onder het kleed?) een levend persoon, in nabootsing van een lijk, hoewel hij door Gods gratie nog leeft in lichaam en geest. Zoo moet hij dan aandachtig een mis aanhooren. Dan zegt de priester tot den leproos: Indien gij [voortaan] wilt drinken, dan moet gij het water scheppen met uw napje, of een ander bakje. Ook verbied ik $U$ rond te loopen zonder het leprozen-kenteeken, opdat andere menschen u mogen vermijden. Desgelijks moogt ge niet ongeschoeid buiten uw woning komen", enz.

Uitvoeriger nog wordt de dienst beschreven in WETZER's Kirchen Lexikon. "Nadat de priester den leproos vermaand had een goed christen te blijven, werd over hem, als over een van de gemeenschap zijner medemenschen afgestorvene, een lijkdienst gelezen. Alle gereedschappen, die hij voortaan zou gebruiken werden gezegend. Het werd hem verboden de woningen der menschen te naderen, zich in bronnen of stroomende wateren te wasschen; voorwerpen die hij dacht te koopen aan te raken, alvorens zij zijn eigendom waren; op smalle paadjes te loopen; het touw van de put of van het rundvee mocht hij niet beroeren, noch uit iets anders dan zijn eigen nap drinken. Vervolgens werd hij, met het kruis voor hem uit gedragen, door de geestelijkheid en de geloovigen naar zijn woning gebracht. De priester wierp aarde van het kerkhof op het bed van den leproos, of wel een zode van den godsakker op diens dak, met de woorden: Weest afgestorven voor de wereld, doch leeft weder voor God. Met cen toespraak en het ophangen van een offerbus, werd hij dan aan zijn treurig lot overgelaten. Van dat oogenblik af moest de leproos een voorgeschreven gewaad dragen, zijn handen bedekt houden en met een klep waarschuwen als hij naderde. Slechts met Paschen mocht hij zijn eenzaam verblijf verlaten en in de stad komen."

Buiten de meesten onzer steden, liefst aan een weg met drukke passage, stonden de voor de melaten aangewezen woningen. 's Hertogenbosch bezat reeds zulk een gesticht vóór $\mathrm{r} 273$; te Arnhem werd er een gebouwd in 1395; het Nijmeegsche leprozenhuis wordt voor het eerst genoemd, in I4I2, doch was van 
ouderen datum, daar het in dat jaar door den stads timmerman „verleegt" werd. Deze gestichten waren stedelijk eigendom en werden gedeeltelijk op stadskosten onderhouden, doch de verpleging der melaten werd grootendeels aan de openbare liefdadigheid overgelaten.

Werd een dorpeling besmet, dan kwam zijn onderhoud geheel ten laste zijner dorpsgenooten. Een nauwkeurige inventaris van wat den plattelands leproos toekwam, geeft een reglement dat in de $\mathrm{I} 6 \mathrm{e}$ eeuw van kracht was voor het bisdom van 's Hertogenbosch. Daaruit blijkt, dat, wat huiselijk comfort aangaat, de leproos het ongetwijfeld beter moet gehad hebben dan vele gezonde landlieden. Men moest een "redelick" goed huis voor hem bouwen, omringd van een muur en voorzien van een schouw. Het meubilair behoorde te bestaan uit een bed met beddekleed en hoofdpeluw, een "saertse" (wollendeken), om de twee jaar een paar lakens; een oorkussen en een wollen kussen; een ledikant (slaepzeil), een stoel, een tafel; een koperen ketel, 6 schotels, een ijzeren ketelhaak, een tang, een rooster, een vuurschop; een hoed, jaarlijks een paar kousen; twee hemden; om de twee jaren 6 ellen grauw laken, om een mantel of cen jas met een kaproen van te maken; om de twee jaren twee par schoenen, een paar met enkele, een met dubbele zolen; een paar handschoenen zonder vingers, een klep en een stok. Zes kippen en een haan moesten in zijn onderhoud voorzien (immers een oud rijmpje zeide: Op zes kippen en een haan, daar kan een boer op staan). Brandhout moest men aan zijn huis afleveren en de gemeente behoorde dat gebouw in goeden staat te houden. Wekelijks mocht de leproos twee of driemaal omgaan in zijn parochie, om giften in te zamelen. Was hij daartoe niet in staat, en kon hij zich zelven niet helpen, dan werd hem een dienaar gegeven op kosten der gemeente, voor wiens onderhoud de broederschap van de H. Geest moest zorgen. Maandelijks moest den leproos worden uitgereikt een pond kaarsen, een kan „raepsmout” (raapolie) en een „selster” koorn. Dagelijks een kan bier; van den H. Geest moest hij altijd een "dubbel portie" ontvangen, daaronder versta men: bij de bedeelingen der H. Geest Broederschap. Elken Zondag werd de melaat door den pastoor aan de gemeente aanbevolen, dat zij hem moesten behandelen, zooals zij zelven in zijn geval zouden wenschen behandeld te worden.

Gewoonlijk stond er bij het melatenhuis der steden een kapel, aan St. Jacob, St. Sebastiaan, of St. Antonius gewijd, waar de godsdienstoefeningen gehouden werden. Dit was ook het geval te Arnhem, waar zulk een bedehuis in 1406 werd opgericht. Het was gewijd aan de H. Maagd, de Heiligen Fabianus en Sebastianus, martelaars, en aan den H. Antonius, belijder, en werd naar dezen laatsten genoemd. De pastoor der kerk van Arnhem en de provisoren van het huis waren de collators. De eerste genoot alle offergaven, die er tijdens de mis 
op het altaar der kapel gelegd werden, alsmede een vierde part der giften, „waaruit die ook mochten bestaan", welke in de offerkist of vóór de beelden gevonden werden. Leprozen, die in het huis kwamen te overlijden, mochten in de kapel of op het daaraan verbonden kerkhof begraven worden, maar niemand anders, uitgezonderd met bijzondere vergunning van den pastoor. Deze bezat ook het recht den kapellaan af te zetten wegens wangedrag. Op elken gewonen dag zou er één enkele mis worden opgedragen; op Zon- en feestdagen echter in het geheel geene, behalve wanneer de heiligen dag van een der patronen, of de gedachtenis der wijding van de kapel op een Zondag viel; overigens alleen met bijzondere vergunning van den pastoor. Deze maatregel was gewis gezondheidshalve genomen, omdat er op Zon- en feestdagen meer menschen op de been waren, die dan allicht de mis in het melatenhuis zouden zijn gaan hooren.

De kapel van het leprozenhuis bij Nijmegen werd bediend door een monnik, bijgestaan door een koster. Wij weten dit uit een procesverbaal van 1560 . Daarin wordt in al zijn geuren en kleuren het wangedrag verhaald van twee leprozen, die op zekeren avond „voll ende droncken wesende" uit de stad naar huis kwamen, waar zij begonnen te vloeken, te zweeren Gods sacramenten, vijf wonden, lijden, enz. Daarop beleedigden zij den monnik en den koster, „myt ontuchtige, onbehoirlicken, lelicken worden ende reden, nyet schryvens oder naseggens behoirlick”, eindigende: „Desen besuyckten (melaatschen) paep ende kuster haldent mitten anderen (elkander), ende steken oeren voet in één schoen. Wij willen den dieffschen monick in siin kamer sluyten ende een cluysteren (hangslot) van buyten dair voir hangen, dairmyt hy daer nyet weder uyt en kome", enz. enz.

Tengevolge van onzindelijkheid, losbandigheid en de lage trap, waarop de geneeskunde stond, heerschten er in vroegere eeuwen allerlei afzichtelijke huidziekten, die, daar de diagnose der lepra onbekend was, al aanstonds voor deze ziekte gehouden werden. Ten einde dit te onderkennen, moest de patient "bezien", onderzocht worden. Op dat gebied waren er specialiteiten, en waarschijnlijk nog meer kwakzalvers. Zoo werd in Deventer in $\mathbf{I} 380$ zekere EvERT JOHANNESz. VAN DER EEZE, als deskundige „gededinght (aangenomen), dat hi di leprose lude besien solde, die binnen onse stat woenen." Hij ontving zes oude schilden voor zijn loon. VAN DER EEZE schijnt een reizend geneesheer geweest te zijn, zooals er toen zoo velen waren, maar daarom nog niet noodzakelijk een kwakzalver. Hij vertoefde blijkbaar slechts tijdelijk in Deventer, want Rykeland WenTFELTS, zijn hospita, ontving van stadswege $5 \mathrm{gl}$. I6 st., die hij, ,in horen huyse vertert hadde, in die tiit dat (hi) die leprose lude gheprovet hadde." In zijn arbeid werd VAN EEZE bijgestaan door een edelman uit een thans uitgestorven Twentsch 
geslacht, jonker vaN DER MARck TOT EvERLo, en diens knecht. Hoewel deze beiden „vor hoer arbeyt dat sie deden, do onse stat die leprose lude hadde laten proven, 16 st." ontvingen, had men daar toch zeker te doen met een dier edele, zelfverloochenende menschenvrienden, waarvan de kroniekschrijver DE VITRY boven gewaagde.

In 14I3 werd door graaf WILLEM VI van Holland bepaald, dat alle degenen die met melaatschheid besmet waren in de provinciën Holland en Zeeland, „ter proeve van den lazerye”, konden gaan ,buten onse stede van Hairlem, binnen den ban van Adikendam (Akendam) in Sinte Jacobs Cappelle, daer de lazeruse lude nu ter tiit in wonen." Hoe dat onderzoek plaats greep en wie daarmede belast was, schijnt niet bekend te zijn, althans in AlLAN's zoo uitvoerige Geschiedenis van Haarlem is daaromtrent niets te vinden. Het kan zijn dat daar destijds iemand was, ervaren in de diagnose van dyskrasische krankheden, en dat diens methode ook nog na zijn overlijden door de broeders in dit huis werd toegepast. Zeker is het, dat de kapel haar beroemdheid in dit speciale vak door de geheele $\mathbf{I} 6$ e eeuw heen wist te handhaven. Zelfs Aurzing, wiens Beschrijvinge ende Lof der stad Haerlem in 1628 het licht zag, zegt nog

t Sieken buyten Stad daer liggen de Leproosen,

Welck Huys de Graef wel-eer vereerd heeft en verkosen, Want daer de schou sal siin van alle Lazarye,

Al 't land van Holland door, en Seland ook daerbye.

In de $\mathrm{I} 7 \mathrm{e}$ eeuw, toen de melaatschheid zeer aan het afnemen was, waren het de regenten van het Dolhuis te Haarlem, die met het schouwen der leprozen waren belast. Arnhem daarentegen zond zijn melaten ter onderzoek naar Keulen, bij raadsbesluit van 25 Jan. I537. Daarbij werden allen binnen die stad, welke van lazerij verdacht waren, gelast vóór midvasten naar Keulen te trekken om zich te laten schouwen, waartoe hun cen stadsbode zou worden medegegeven. Weigerde zoo iemand die reis te ondernemen, dan zouden de schepenen hem in het melatenhuis doen zetten, en kwam hij weder in de stad, dan verviel hij in een boete van $100 \mathrm{gl}$, half ten bate van de schepenen, de andere helft ten bate van de stad.

Waar Nijmegen zijn melaten ter onderzoeking heenzond, blijkt niet altijd. Het eerste voorbeeld daarvan dat de rekenbocken opleveren, is van 1530. De post dienaangaande bericht alleen dat "een frouw, van oiren man te laten besyen, was hy melaetz offte niet", één gulden ontving. Kort daarop werden aan een man uit Lent, voor een dergelijls doel vier gulden verstrekt. Misschien werd dus het onderzoek in deze beide gevallen in twee verschillende plaatsen 
gedaan. Eerst in 1539 wordt bepaald gezegd, „enen toegelaeten om zich $t$ Harlem laeten $t$ besien, off hy melaetz were, I gl, 4 st.", vermoedelijk ging dan de tocht van Haarlem naar Akendam. Van dien tijd af werden er jaarlijks nooit minder dan vier of vijf, enkele malen tot tien, zelfs twaalf per jaar (b.v. in I557: 7 mannen, 4 vrouwen, I jongen) naar Haarlem gezonden, waarvoor de stad het reisgeld betaalde, dat gewoonlijk I gl. 4 st. bedroeg. Pedibus apostolorum moet dat wel voldoende geweest zijn, daar in 1539 de stadslandmeter vier gl. ontving om een tocht naar $Z$ wolle met oponthoud te bekostigen. De zieken ondernamen den tocht onbegeleid, slechts in één enkel geval werd een bode medegegeven. Dat kwam aldus: in 1559 toog Peter van DE GraefF naar Haarlem "om sich te laten besien van laserie." Hij was een "prawender" (provenier) in Sinter Claes gasthuis. "Ende soe hy een aldt man was, is GEIIT VAN ESSEN, gaende bode, mit hem gereist; ende soe GerIT claechden dat hy lange op weich was, ende meer dan twe gulden brab. vertert hadde, hem gegeven 3 gl. br."

In 1572 , toen Haarlem door Alva's legermacht belegerd en ingenomen werd, trokken onze melaten voor onderzoek naar Keulen. Drie togen in genoemd jaar uit Nijmegen, "den alden gebruyck nae omb sich zo laetten besien to Coelne van der lazerie", waartoe clk hunner twee gulden ontving. Ook nog in 1576 ging er een daarheen, hoewel vier anderen in het jaar te voren Haarlem reeds weder bezocht hadden, en derwaarts lag van toenaf op nieuw voortdurend de reis.

Werd de paticnt te Haarlem bevonden melaatsch te zijn, dan kreeg hij ten bewijze daarvan een gedrukt schouwbriefje. Zulk een berust in het Museum in de Lakenhal te Leiden, en is van den volgenden inhoud, waarbij de cursief gedrukte woorden met de pen zijn ingevuld:

${ }_{n}$ Kenlick si allen luyden, Hoe dat wi ghemee geswore van Sinte Jacobs capelle buyten Haerlem, gheproeft en met alre naersticheydt besien hebben Een manspersoon ghenoempt Quiriin Fansz van Leyden, Welcke wy nu ter tiit Mellaets wt-gheuen besmet te wesen met Lazerye, waeromme dat hi gaen sal met vlieghers, Een Clap hebbende op die borst, Een witte bant om thooft. In kennisse des waerheyts soe hebben wi ghemeen ghesworen voorschreuen Desen brief besegelt met ons ghemeen seghel. Int Jaer ons Heere Duysent vyfhondert ende twee cnde tsoeventich, den sesten dach Fanuarii stylo coi (communi)".

Een tweede briefje, gedagteekend 22 Maart I6I2, berust in het Geneeskundig Museum te Amsterdam, en was te zien op de Historisch Geneeskundige Tentoonstelling te Arnhem, in de maand Juli I 899. Het is gedrukt op een strookje perkament, omtrent I 5 cent. lang en bijna woordelijk van denzelfden inhoud als het vorige, met dit verschil in de kleedij: "een zwarte hoet opt hooft, becleet 
met een witten bandt, sonder ander bant”. Voorts de toevoeging: "Ende desen brief out synde vier jaeren, is doot ende te niet." Het zegel vertoont St. Jacob in groene was.

Bleek bij het onderzoek dat de zieke niet aan leprozij leed, dan ontving hij een ggesontbrief" Daar dit voortdurend heen en weder trekken van melaatschen naar Haarlem de besmetting moest bevorderen, werd bij plakkaat van 13 Oct. 1586 bepaald dat alleen zieken uit Holland, Zeeland en Westfriesland zich aan de Kapel te Akendam mochten laten onderzoeken, die daartoe moesten voorzien zijn van een certificaat, afgegeven door den magistraat hunner geboorteplaats. Doch aan deze beperking werd evenmin de hand gehouden als vroeger.

Pogingen tot genezing schijnen, althans onder den minderen stand, weinig of niet te zijn aangewend. Dienaangaande is het eenige wat in de Nijmeegsche rekenboeken voorkomt een post van 28 Nov. I609: „betaelt mr. HaNs scherprichter, voor de cure van sekere arme melaeten vrouw, I 5 gl." Dat deze beambten zich met genees- en vooral met heelkunst afgaven, was destijds niet zeldzaam.

Het was een volksbijgeloof dat Leprozij alleen kon genezen worden door boete doen en door zeven jaren lang gebedeld brood te eten. Inderdaad, ten gevolge van hun weerzinwekkend uiterlijk en der vrees voor besmetting, konden deze paria's geen dienst, noch werk vinden om den kost te verdienen, en bleef hun dus niets anders over dan te bedelen. Want het melatenhuis blijkt geen voedsel verstrekt te hebben, aileen onderdak. Ook zij die daar gehuisvest waren leefden van aalmoezen. Daarom verzochten de provisoren van het leprozenhuis buiten de Noordpoort te Middelburg, in I540, aan den magistraat, om dat huis naar een andere plaats te mogen overbrengen, waar meer passage was, immers, aldus het request, de arme lazarussen konden alleen leven van de aalmoezen die hun werden uitgereikt, aangezien het hun verboden was zich onder de menschen te begeven.

Uit teekeningen in vroeg-middeleeuwsche handschriften blijkt, dat de bedelende melaten destijds naakt door de straten liepen, alleen met een lendendoek omgord. Zij droegen een koehoorn aan een touw gehangen, ten einde daarmede voor hun nabijheid te waarschuwen. Zoo ziet men ze afgebeeld in een codex van de tiende eeuw, afkomstig uit de abdy te Essen, thans in de Landsbibliotheek te Dusseldorp. Het gansche lichaam dier ongelukkigen is daar getijgerd met roode vlekken of builen. Ook in handschriften van Trier en van Gotha loopen zij met een horen. Doch in een gedicht van ULRICH VAN LICHTENSTEIN'S Frauendienst (eerste helft der I 3 eeuw), kloppen zij op hun drinknappen, terwijl 
$z i j$ in een geschilderd venster in de kathedraal van Bourges, uit de $13^{\mathrm{e}}$ eeuw, reeds van kleppen voorzien zijn.

Te Amsterdam ontvingen de melaten, die te Haarlem "vuil geschouwd" waren, verlof te bedelen met een klep, waarop het wapen van Haarlem stond. Zulk een leprozenklep zag men op de bovengenoemde Historisch Geneeskundige Tentoonstelling in I899. Dat exemplaar was een houten instrument, in den vorm van een gesloten waaier, doch eenigszins breeder. Van boven af was het tot op een derde zijner lengte in tweeën gespleten, waarbij de voorste helft met een scharnier aan het achterstuk bevestigd was. Door een beweging met de hand kon men de beide deelen tegen elkander laten kleppen. Een ander was gevormd uit een hout omtrent $20 \mathrm{cen}^{\mathrm{r}}$. lang, uitloopend in een ovalen houten schijf, waaraan onder en boven twee andere plankjes van denzelfden vorm met scharnieren bevestigd waren. Op deze klep was het oude wapen van Gouda, twee sterren, gebrand. Een derde vorm wordt beschreven in de Navorscher, deel III, als een houten schijf met een steel bij wijze van een lepel. In de schijf was een holte aangebracht, om de almoezen in te ontvangen, zoodat de gever de hand van den melaat niet behoefde te beroeren. Over de schijf was een andere van dezelfde grootte bevestigd, welke diende als deksel en tevens om te kleppen. De inzender dezer beschrijving voegt er bij, dat hij in zijn jeugd (hij schreef in 1853) nog een paar menschen, geen melaten, gezien had, niet tot den armen stand behoorende, die toch met de klep aan de huizen hunner gegoede geloofsgenooten gingen bedelen. Ook in het Bijblad van de Navorscher Deel V, herinnert zich iemand in zijn jeugd, op zomerdagen, aan de stadspoorten of op wandelingen, personen te hebben zien bedelen ,met een klep tusschen de vingers". Gewoonlijk waren het lieden die aan hoofdzeer leden. Bij hen schijnt dus nog een traditie uit den melaten-tijd te hebben bestaan.

Met hun geklep waarschuwden de leprozen voor hun gevaarlijke nabijheid, en trokken zij tevens de aandacht op zich, ten einde de liefdadigheid op te wekken. $\mathrm{Z}_{\mathrm{ij}}$ moeten een druk gebruik gemaakt hebben van hun instrument, want nog hoort men wel opmerken van iemand die onophoudelijk babbelt: „zijn tong gaat als een lazarusklep." Desgelijks zou, naar men beweert, het werkwoord klaploopen afgeleid zijn van het loopen bedelen "op de klep", zooals die boven beschreven is.

Een schilderstuk van den Antwerpschen schilder SebastiaAn VRancx, in de Alte Pinacotheek te Munchen, gedateerd I622, stelt voor een Vlaamsch of Nederlandsch dorpsfeest. Op den voorgrond rechts, een weinig afgezonderd van het feestgewoel der landlieden, ziet men een groep van zeven leprozen, waarvan twee vrouwen, te samen op den grond gezeten, zich te goed doende aan spijs 
en drank. Hun kleedij is onmiskenbaar. Beide geslachten zijn gehuld in zwarte mantels, met een groote witte L (leproos of lazarus) op de linkerborst. Zij dragen breedgerande slappe hoeden, met een witten baild omgeven, zooals voorgeschreven is in het Haarlemsche briefje van van 1612, Elk hunner heeft een klep van den bovenbeschreven gesloten-waaiervorm. Denkelijk is de mantel, dien zij aanhebben, dat kleedingstuk dat in de bedoelde briefjes een "vliegher" genoemd wordt. KILIAN althans beschrijft den vlieger in zijn Woordenboek als „een vrouwelijk gewaad dat van voren opengaat, en als twee vleugels verdeeld is"; waarbij VAN HASSELT aanhaalt: ,sijn beste kleedingstuk, t zij mantel, hoeyck, vlieger, ofte bouwen." Te Nijmegen ontving een melaat in I 539 van stadswege een gulden ,tott een grouwen mantell te koepen". Dat de leprozen daar ter stede eveneens met de klep plachten te loopen, blijkt uit het volgende. In I 569 werden aldaar twee moordenaars geradbraakt, aangaande welke executie het rekenboek een post bevat van dezen inhoud: "Soe die een moerder lazarus was, gekofft eenen box (bus, om te bedelen), die opt rat genegelt wart. Item GoERT KETEL een lazarusklep gemaeckt, die aen dat rat gehangen werd." Met dergelijke voorwerpen werden den volke nadere inlichtingen gegeven omtrent den persoon der geëxecuteerden en hun misdrijf. Een valsche munter b.v. werden bij zijn terechtstelling groote blikke penningen op de borst gehangen; blikke kelken toonden den kerkedief aan, een vuurtest den brandstichter. Somtijds ook werd het mes of een ander werktuig waarmede een moord gepleegd was, aan het rad gehangen.

Het bedelen der melaten was in de meesten onzer steden door keuren en ordonnantiën beperkt. Een bepaling van den Arnhemschen magistaaat van 1437 verbood den melaten uit het leprozenhuis, in de stad te komen bedelen langs de huizen en op het kerkhof te gaan zitten, "als sy tot hyer toe gewoentlick siin geweest." Den melaat die tegen dit voorschrift handelde, werd het verblijf in het gesticht ontzegd. Doch hun knechten die gezond waren, mochten wekelijks (ter weke) rond gaan bedeien en op het kerkhof zitten, „als sy tot hyer toe gewoentlick ziin gewest." Vreemde melaten moesten fluks door de stad gaan en daar niet vertoeven. Veel minder streng waren de bepalingen die te Nijmegen in 1559 gemaakt werden. Daar was het den bewoners van het leprozenhuis veroorloofd des Zondags, Woensdags en Vrijdags in de stad te komen bedelen, doch die "van buyten”, de vreemde melaten, konden alleen Donderdags omgaan om liefdegaven in te zamelen. De portiers aan de stadspoorten hadden last hen respectievelijk alleen op die dagen binnen te laten. Nog in 16 I I werd vastgesteld dat het dien uit het melatenhuis alleen vrijstond op Woensdagavond en des Donderdags in de stad te komen, "soe als dann hem by d'ordonnantie daerop 
gemact, hier te verblyven ende omme te gaen toegelaeten is." Vreemde melaten die op de hun verboden dagen, "buiten tiits”, bedelend werden aangetroffen, moest de gezworen omroeper uit de stad doen vertrekken. Het stadrecht van Kampen bepaalde dat "arme lieden die lasars sind", slechts viermaal 's jaars in de stad mochten komen. Drie dagen lang konden zij dan in het St. Catharinen gasthuis vertoeven "ende sullen ter maeltiit hebben eeten, drincken ende genieten gelijck die ander daer in den huse wonende off geprovent, anders niet".

Dus werden, door een verkeerd toegepast mededoogen, de leprozen niet geheel uit de samenleving afgezonderd. Men veroorloofde hun zich onder het gezonde deel der menschheid te mengen, ten einde hun geldelijken steun te bezorgen. Nijmegen geeft daarvan nog andere voorbeelden. Het rekenboek van I 592 bewijst hoe in dat jaar een leproos dagenlang baksteenen, van afbraak afkomstig, heeft "gefecht", d. w. z. afgebikt. Maar in die dagen toen men nog geen vrees voor bacillen, noch microben kende, deed men zelfs wel erger. Een besluit van den Nijmeegschen raad van 20 Sept. I6II, behandelt het verzoek van vreemde melaten, om op Maandagen in de stad te mogen rondgaan, ten einde lun waren te verkoopen. Daar Maandag de drukste marktdag was, vond de magistraat dat verzoek wel wat bedenkelijk; doch hij zag er geen bezwaar in hun toe te staan met hun waren "onder taffdack van 't gasthuys aan de Grootestraat te mogen voorstaen, sonder dat sy daermede langs de straeten sullen gaen mogen, off eenige almoesen alhier vergaderen, noch oock den leprosenhuys alhier lastich [te] siin." En op diezelfde bank waarop de leprozen hun besmette waren te koop stelden, werd N.B. de visch verkocht, want het benedeneinde der Grootestraat deed destijds dienst als vischmarkt.

Te Amsterdam was het in de $17^{\mathrm{c}}$ eeuw den leprozen verboden in de stad te loopen bedelen, maar daarom was men overigens niet voorzichtiger. Eenmaal in het jaar mochten zij daar een omtocht houden, die twee dagen duurde, ten einde liefdegaven in te zamelen voor het onderhoud van hun gesticht. Er bestaat een groot schilderstuk door ADRIAAN VAN NIEUWLANDT, in 1633 vervaardigd, en in I769 door Simon FoKKE geëtst, ten opschrift dragende: "Jaerlykse ommeganck der Leprozen, op Copperties-Maendag, opgehouden in 't jaer I604." Coppermaandag, elders Razende-, Verzworen-, Blijde-, Zotte-, Verloren Maandag, was in ons land en elders een der drukste, woeligste volksfeestdagen van het gansche jaar. Het straatpubliek was dan in een opgewonden, vrijgevige stemming, en deswegen had men dien dag in Amsterdam gekozen voor den optocht der leprozen. Op het schilderij van VAN NIEUWLANDT passeert de stoet den overvollen Dam, waar een soort van kermis schijnt gehouden te worden. Voorop marcheert een tamboer, in het zwart gekleed, hem volgt de blazoendrager van het Houtzagersgild, 
dat den ommegang, althans in dat jaar, vergezelde. Ter wederzijde van hem gaat een binnenmoeder van het leprozenhuis, met een bord in de hand, waarover een witten doek met roode kwasten, om aalmoezen te ontvangen. Dan volgen de leprozen, deels te voet, deels in negen sleden gezeten, door paarden getrokken. In elke slede bevinden zich een man, een vrouw en een kind. De vrouwen hebben borden voor liefdegaven op haar schoot, en een ledig tonnetje naast zich, om het bord in te ledigen telken male als het vol mocht worden. 's Maandags nam deze optocht zijn weg aan de Oude-, Dinsdags aan de Nieuwe Zijde. Een feestmaal werd den leprozen aangeboden op den eersten dag in het het St. Petri-, den volgenden dag in het Burgergasthuis, en door beide gestichten werden zij rijkelijk getracteerd.

Dergelijke gastmalen werden aan de Nymeegsche melaten niet geboden, doch met de gemoedelijkheid die karakteristiek is onzer oude tijden, viel er bij stedelijke feesten voor den armen lazarus nog wel een kruimke van den welvoorzienen disch der rijke brassers. Zelfs nog in I584, toen vele aan de oude godsdienst verbonden gebruiken waren afgeschaft, werd aan de melaten, "nae den aldenn gebruyck gegeven, doenn een erbar raeth geteerdt, een flesch wijn van I gl. 4 st." Daarbij denke men niet aan onze pygmeën flesschen; het was een tijd toen een kwart goeden wijn zeven stuivers kostte en de flesch dus omtrent

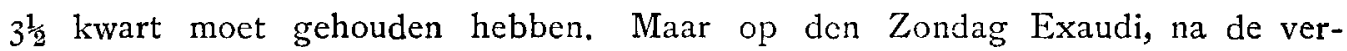
kiezing der meesters van Sinter Claas kregen zij slechts twee kwarten. In I 586 bij deselfde gelegenheid ,an den leproesen vur hoer maeltiit, r gl. ro st." In I59I staat er bij, dat de I gl. 4 stuivers gegeven werden aan "die vier personen int Lazarushuys, voer haer deel in den maeltiit." Ook nog na de reductie der stad, I 593: „Den armen melaetten voer ein vlesch winss haer luyden, nae alder gewoendenn, als voer het hoechgetiit van Paeschen competerende, I gl. 4 st. Item betallt aen den melaetten voer een vlesch wins, hoen op St. Martinus aventt toekomende, I gl. 4 st." Desgelijks op O. L. V. avond, op Kerstmis en op Nieuwjaar. Niet lang daarna evenwel viel deze gewoonte in onbruik.

Hoe vreeselijk de kwaal ook was, waarmede de leprozen bezocht waren, men stelle zich niet voor dat het een droefgeestig volkje was. Hun kwaal was een kapitaal dat goede renten afwierp, en van die renten leidden zij op hun manier een leventje, zooals de Duitschers dat uitdrukken, "wie der Herr Gott in Frankreich". Er waren er die hun geluk in den huwelijken staat zochten en onderling trouwden, over welke huwelijken in 1470 in Overijssel een rechtsgeleerd advies werd gegeven. Bij een Nijmeegsch raadsbesluit van 20 Sept. I 592, werd zekere melaat "een onmelaatsche dochter" getrouwd hebbende, alsmede drie andere melaten, achter het Hof wonende, gelast naar Haarlem te reizen, en van- 
daar "schijn en getuychnisse te brengen van heuer suyver- ofte onsuyverheitt, om, 't selve gedaen, bii miin heeren ten respecte van heuer woonplaetse gedisponeert te worden nha behoeren," of zij namelijk in het leprozenhuis konden gaan of niet. De R. K. Kerk had haar eigen bepalingen omtrent huwelijken van leprozen. Verlovingen werden ontbonden als een der partijen melaatsch werd, en voor een gesloten huwelijk kon men dispens verkrijgen. Aan den anderen kant eischten twee pauselijke canons (de Conjugio Leprosorum) dat de gezonde echtgenoot met de of den leproos moest blijven samenwonen. Doch deze bepalingen werden door de canonisten, onder zekere beperkingen, alleen van toepassing geacht, wanneer de ziekte van dien aard was, dat cr geen gevaar van besmetting bestond.

Weinig leprozen waren echter zoo betamelijls van aard, dat zij met het huiselijk leven genoegen namen. Hun ziekte bracht verhoogde zinnelijke neigingen mede, en daaraan werd rijkelijk den vrijen teugel gelaten. Dat was de reden waarom velen hunner liever in vrijheid bleven rondloopen, zich aansloten bij vagabonden, bedelaars, landloopers en ander gespuis, dan zich te onderwerpen aan de tucht die het melatenhuis medebracht. In het cartularium van Notre Dame te Parijs vindt men dienaangaande de volgende resolutie van den Aartsbisschop, van het jaar I20x. "Daar er omtrent de losbandigheid der leprozen zulke ergerlijke klachten tot ons zijn gekomen, hoe zij namelijk, die zich mocsten afzonderen van het algemeen verkeer, zich thans, niettegenstaande de wettelijke bepalingen, overal, met meer vrijheid dan recht, vertoonen en vrijelijk rondloopen; zoo hebben wij, ten einde, zooals onze herderlijke plicht medebrengt, het gevaar tegen te gaan dat uit zulk een vermenging voortdurend blijft ontstaan, en opdat niet, hetgeen de Heer verhoede, de ziekte zich zoo zecr uitbreide dat de gansche kudde besmet wordt, goedgevonden de zieke schapen uit de gezonde kudde te verwijderen, het ongeoorloofde rondloopen der leprozen verboden, en hun bandeloosheid tot het betrachten van bepaalde statuten doen dwingen. Uit naam en met goedvinden van vrouwe ADELA, doorluchtige Koningin van Frankrijk, bevelen wij, dat alle leprozen in de kastelanijen van Melun en van Corbeil slechts op twee plaatsen zullen vertoeven, namelijk de mannelijken in het huis van St. Lazarus te Melun, de vrouwelijke in dat van St. Lazarus te Corbeil, in dier voege dat noch de mannen bij de vrouwen, noch de vrouwen bij de mannen mogen komen, noch samenwonen."

De melatenhuizen in Nederland waren gewoonlijk eigendom der steden, werden door haar ten deele bekostigd, en stonden onder toezicht van provisoren. Te Nijmegen werden alleen burgers in het gesticht opgenomen. Meestal was er een vrouw, de moeder, gesteld aan het hoofd van het huishouden. Zoo eene 
reedt te Nijmegen voor het eerst op in een raadsbesluit van 1562 , en daar dit enkele huiselijke aangelegenheden bevat, moge het hier volgen: "Dewiil die maghet van den lazarushuys gepeyndt is van kerssen (kaarsen) ende anderss noitdrufft des huys om to betalen, diewelcke parselen voornoemt opgemelte maghet verclaret by oiren eide volstaen, ende dat JoHAN SPRUYT, provisor, die verteringe betalen sall. Doch woe die provisoren bedunckt dat die maghet onredelick sy, hebben sy die orloff tho geven ende eyn andere tho stellen." Verder blijkt dat er in 1552 een "taeffel tot den melaeten gehangen" werd, "haldencle oer leges," en dat deze op nieuw in 1567 door een der secretarissen "in $t$ rein gesteld ende op een bret (plankje) gecleft" werden. Jammer genoeg is er geen exemplaar dier verordeningen bewaard gebleven. In 1534 bezat het gesticht een "peerdtgen", dat van de stad een malder haver ontving, omdat sommige raadsvrienden het ,in onser raedt saeken" gebruikt hadden.

Dat er een cantine aan het gesticht verbonden was, blijkt uit het rekenboek van $155^{\circ}$, betreffende een vertering van elf snaphanen "totten melaeten" gemaakt door den scherprechter en zijn acolyten, op een nacht dat zij daar in de buurt, op het Galgenveld, de galg opstelden. Omtrent die cantine vindt men in het Liber Depositionum Testium van 1562 eenige merkwaardige bijzonderheden. In een quaestie betreffende den bieraccijns betuigen drie leprozen, op 5 April, dat sedert BAET, de maagd, laatstleden Oegst (Augustus) in het melatenhuis was begonnen te tappen, zij ongeveer veertig vaten bier vertapt en verbruikt had. Zij nam voor clke vaan een pertje ( $\mathbf{r}^{1} / 2$ st.), ook wel een pertje en een penningske, al naarmate de prijs in Nijmegen was. Verder beweerden zij, dat BAET en NAEL Voss hun hadden gezegd, dat zij menschen wisten die jaarlijks gaarne een Joachimsdaalder zouden willen geven, als men de zeep, de kaarsen en wat verder in het huis noodig was, bij hen ging koopen. Twee andere leprozen legden hetzelfde getuigenis af, omtrent den prijs van het bier, en voegden er het merkwaardige detail bij, dat die prijs ook betaald werd door „alle vremde luidde, die aldaer ter tiit om te drincken quamen!"

Nadat Nijmegen zich in I 579 van zijn Spaansch garnizoen bevrijd had, stond het te vreezen dat de Spanjaarden pogingen zouden aanwenden om deze belangrijke vesting weer in hun macht te krijgen. Dientengevolge besloot men haar in behoorlijken staat van verdediging te brengen, en te beginnen met verschillende gebouwen in de onniddellijke nabijheid af te breken, daaronder was ook het melatenhuis. Uit de posten in het rckenboek die op dit werk betrekking hebben, blijkt dat dit gebouw met een "singelmuer" omsloten was, waarvan 25,300 baksteenen kwamen. De melaten zouden tot nader order hun intrek nemen in de woning van den pater van het St. Agnietenklooster, aan den Tcers, 
te Neerbosch. Daar bleven zij tot hun in I58I een verblijf werd aangewezen in het ziekenhuis van het Observantenklooster. Het leprozenhuis werd eerst in het volgende jaar afgebroken, en de baksteenen die er van kwamen, werden gebruikt om de Hersteegpoort mede toe te metselen. De kapel volgde al spoedig.

In het Observantenklooster bleven de leprozen niet lang, reeds in het volgende jaar besloot de raad hen "te accomodeeren mit een behuisonghe achter idt Hoff, by de Hoenderpoort." Voor 200 daalders werd dit huis gekocht. Zoo waren zij dan nu in de stad gevestigd. Daar zag men toen geen bezwaar meer in; ook te Amsterdam kwam het leprozenhuis dat aan den Oudendijk gestaan had, door de uitbreiding der stad in 1593 binnen de muren te staan. Achter het Hof te Nijmegen was daarenboven een slecht befaamde buurt. Daar woonden allerlei onzuivere elementen : de scherprichters, de vilders, schoorsteenvegers, destijds ook geen eerbaar bedrijf, „goudgravers" of stillevegers,

Ambubaiarum collegia pharmacopolae

Mendici, mimae, balatrones, hoc genus omne.

De tuin van het lagere gedeelte van het Hof, tusschen den Voerweg en de Waal, beslaat thans de plaats dier poel van ongerechtigheden. In het huis aldaar vertoefden de melaten tot 1638 , toen een woning in de naburige Goltgravers'-, later Rozemarijngas tot melatenhuis werd aangewezen. Het oude huis was bouwvallig en stond op dat oogenblik ledig; er waren geen melaten meer in. Inderdaad was de melaatschheid sedert het begin der $\mathbf{I} 7^{e}$ eeuw hier te lande sterk aan het afnemen. Het leprozenhuis werd dan ook in 1650 bestemd tot passanten huis voor doortrekkende melaten en bedelaars, en den diakenen in $165 \mathrm{I}$ bevolen de "passeerende" bedelaars geen geld meer te geven, maar een loodje ter hand te stellen, dat hun recht gaf om eén nacht in het Gasthuis of wel in het melatenhuis te logeeren. Zekere LiJDA Steknacker, een schoolmeester's dochter, die verlof had om te bedelen, dewijl haar kind "laserus" was, werd nu aan het hoofd van dit gesticht gesteld, met een tractement van 23 gl., "als van oudts." Maar op den duur ging het niet met dat huis. Er kwamen klachten dat schooiers, die zich voor melaatschen uitgaven, in de stad liepen te bedelen en het gebedelde dan in het melatenhuis's avonds en 's nachts „met drincken, speelen, danssen ende springen onnuttelick" verbrasten. Bevel werd daarom gegeven aan den huisbaas van dit gesticht, om geen leprozen meer te huisvesten, noch onderstand te geven. Toch vernam de raad in het volgende jaar, dat er , in die woninghe van de leprosen, by die vremde leprosen en de andere bedelaers een ongeregelt leven gevoert ende ontuchtich huys gehouden werd." Men besloot daarom het huis te verhuren. In $\mathrm{I} 66_{3}$ werd het "huys van de Blaten" (aldus 
het Nijmeegsch idioom voor melaten) eindelijk voor goed an zijn vroegere bestemming onttrokken, en met de bleek en de daarop staande pomp verhuurd, terwijl de fondsen van het gesticht werden overgedragen aan het voormalige Cellenbroederenhuis, ten bate der krankzinnigen.

Een straatje te Nijmegen, dat thans van den Lindenberg naar een der beneden ingangen van het Hof leidt, is officiëel bekend als de Langebaan, doch draagt bij oude Nijmegenaars nog steeds den naam "Achter den Blatum", omdat het weleer achter het laatst behandelde melatenhuis omvoerde.

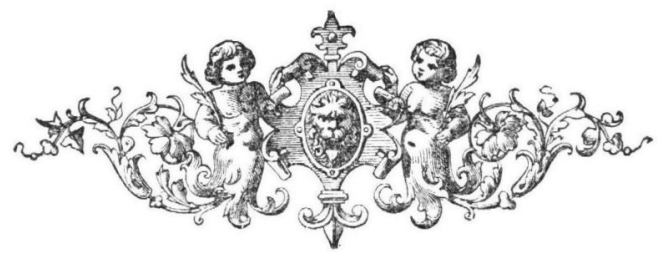

